\title{
Carcass and pork quality traits of indigenous pure breeds (Mangalitsa, Moravka) and their crossbreads
}

\author{
C. Radovic ${ }^{*}$, M. Petrovic ${ }^{1}$, N. Parunovic ${ }^{2}$, D. Radojkovic ${ }^{1}$, R. Savic ${ }^{1}$, N. Stanišic and M. Gogic \\ Institute for Animal Husbandry, \\ 11080 Zemun-Belgrade, Serbia.
} Received: 23-09-2015

\begin{abstract}
Objective of this paper was to evaluate phenotypic variability of carcass side and pork quality traits of fatteners (male castrated and female heads). Investigation included 12 pigs per group of Mangalitsa (Genotype 1), Moravka (Genotype 2), cross-breed Mangalitsa with Moravka (Genotype 3) and cross-breed Moravka with Duroc boar (Genotype 4). Results show that Mangalitsa had lower daily gain $(268 \mathrm{~g})$ than other genotypes $(\mathrm{p}<0.001)$. The greatest difference for fat thickness was determined between Genotype 1 and Genotype 4. As expected, the thinnest fat and maximum value for gain and depth of Musculus longissimus (ML) had the Genotype 4. The highest value for the $M L$ surface was found in Genotype 4(47.52 $\left.\mathrm{cm}^{2}\right)$ whereas for the same trait in Mangalitsa the lowest value was observed $\left(24.16 \mathrm{~cm}^{2}\right)$. Mangalitsa had significantly lower $\mathrm{L}^{*}, \mathrm{a}^{*}$ and $\mathrm{b}^{*}$ values of $M L$ compared with all other groups $(\mathrm{p}<0.001)$. Considering the low production performance of indigenous pig breeds, crossbreeding with the Duroc breed will contribute a improvement of growth and carcass traits.
\end{abstract}

Key words: Color, Genotype, Indigenous pig breeds, Meatiness, pH, Sex.

\section{INTRODUCTION}

Local (indigenous) pig populations are usually constituted by a quite low number of active boars and sows. Their pedigree information is lacking or absent, complete phenotypic description is usually not available for most of these populations that are very well adapted to specific local agro-climatic environments. The population of Mangalitsa and Moravka breed is endangered and risky endangered. Small number of both indigenous breed produce many negative effect (low reproductive performance, high mortality, low daily gain, etc.). In Europe, a large number of indigenous pig breeds is nearly extinct. Serbia already lost 2 indigenous pig breeds (Šiška and Šumadinka breeds) which belonged to the most primitive breeds of pig - fatty breeds.

In Republic of Serbia today, there are three registered native, indigenous breeds: Mangalitsa, Moravka and Resavka. Mangalitsa (Swallow-Belly Strain) is found on the territory of Srem (vicinity of Ruma, village Budanovci, and the residents of this village in Srem are called "Lasans") and is typical fatty pig breed. Because the meat and adipose tissue as well as meat products of Mangalitsa are much appreciated by the Serbian consumers, the scientific efforts were not limited to preserve the breed as such but also to better exploit its potential for human consumption. It has in carcass sides $65-70 \%$ of fat and approx. $28-35 \%$ lean meat (Egerszegi et al., 2003; Petrovic et al., 2009). Today, the Mangalitsa breed is reared in an organized system in several herds in the Republic of Serbia and is the most numerous indigenous pig breed. Moravka and Resavka are breeds of combined production abilities, reared in the same region of Serbia, and were studied in comparative research (Živkovic and Kostiæ, 1952). Moravka has somewhat more lean meat in carcass sides and considerably less fat than Mangalitsa (Petrovic et al., 2007a).

One of the indicators of technological quality of meat is a muscle $\mathrm{pH}$ value. On the varying of the $\mathrm{pH}$ values some other factors such as: growing conditions, nutrition, transport, procedures on animals pre-slaughter, during processing on the slaughter line and cooling of carcass halves exert their effect. Values of $\mathrm{pH}$ of muscle is about 5.6-5.7 of a "normal" quality within 6-8 hours after slaughter, and then to about 5.3-5.7 after 24 hours (Janicki and Buzala, 2013). The color and appearance of meat are crucial for making decisions while buying meat. Unusual and changed color of meat and release of fluids act repulsive to the customers.

Objective of this paper was to evaluate phenotypic variability of carcass and some meat quality properties of indigenous pure breeds, Mangalitsa and Moravka, and their available cross-breeds.

\section{MATERIALS AND METHODS}

Animal trial: Research was carried out on pig farm and in experimental slaughterhouse of the Institute for Animal Husbandry, Belgrade, Serbia. Investigation included heads of Mangalitsa (Genotype 1), Moravka (Genotype 2), crossbreed Mangalitsa with Moravka (Genotype 3) and cross-

\footnotetext{
*Corresponding author's e-mail: cedomirradovic.izs@gmail.com; 'University of Belgrade, Faculty of Agriculture, 11080 Zemun-Belgrade, Serbia. ${ }^{2}$ Institute of Meat Hygiene and Technology, 11000 Belgrade, Serbia.
} 
breed Moravka with Duroc boar (Genotype 4). The investigation included 12 pigs per group. Besides the genotype as fixed factors in the model included sex of progeny (per genotype, 6 animals were male castratessurgical castration and 6 animals were females). A traditional low-input technology was applied. Apart from pasture, the pigs were given of corn (to $0.3 \mathrm{~kg} /$ animal/day).

Evaluation of carcass and pork quality traits: Preslaughter mass, mass of warm and cold carcasses were measured with accuracy of $0.5 \mathrm{~kg}$. On slaughter line, linear measures of warm carcass sides were taken. Fat thickness was measured in the middle of the back where fat tissue is the thinnest (between $13^{\text {th }}$ and $15^{\text {th }}$ vertebrae; FTMB) and withers back fat thickness (WBF). Back fat thickness was measured with accuracy of $1 \mathrm{~mm}$. Yield of meat was determined on cooled left carcass sides by method of partial dissection (according to methodology recommended by EU Comission Regulation (EC) 1249/2008; Walstra and Merkus, 1996).Percentage of meat in carcass sides was calculated using two formulas/equations:

1. Commission Regulation EC No $3127 / 94$ (EC 94):

$$
\begin{aligned}
& \text { weight of tender loin + weight of lean (fascia included) } \\
& \text { in shoulder, loin, ham and belly }
\end{aligned}
$$

2. Commission regulation EC No 1197/06 (EC 06):

$$
y=0.89 \times 100 \times \frac{\begin{array}{c}
\text { weight } \text { of tender loin }+ \text { weight of lean (fascia included) } \\
\text { in shoulder, loin, ham and belly }
\end{array}}{\text { weight of tender loin }+ \text { weight of dissected cuts }}
$$

Measuring of mass of warm carcass sides was done $45 \mathrm{~min}$ post-mortem, and before cutting on warm right carcass sides, percentage of muscle tissue was assessed by simulation of the instrumental method FOM and lean meat content in carcass sides and class of carcass sides was determined (SEUROP classification system). According to formula defined by Radovic et al. (2010), content of meat was determined by measuring of the fat thickness on two locations/points which are adequate to positions where FOM probe is inserted (LF and RF) and diameter (RM) of Musculus longissimus(ML), where: LF - fat tissue thickness (with skin) in millimetres, measured $8 \mathrm{~cm}$ away from medial carcass line, between $3^{\text {rd }}$ and $4^{\text {th }}$ lumbal vertebrae, from caudo-cranial point of view; RF - fat tissue thickness (with skin) in millimetres, measured $7 \mathrm{~cm}$ from medial carcass line, between $3^{\text {rd }}$ and $4^{\text {th }}$ rib, from caudo-cranial point of view; $\mathrm{RM}$ - diameter of ML in millimetres, measured at the same time and same position as RF. In accordance to regulations of the majority of EU countries, linear measures of LF, RF and RM were taken manually using a ruler. Based on obtained results, percentage of meat in carcass sides was calculated using mathematical model defined and presented in the proposal of the Regulation on quality of slaughtered pigs:

$$
Y=55.6925-0.2402 L F-0.4575 R F+0.1578 R M
$$

Meatiness was also established using "Two-point method" (Radovic et al., 2010) as follows: fat thickness was measured at the thinnest point of the rump, i.e. where $M$. gluteusmedius (MGM) penetrated the fat tissue the most (S) and the second measure was depth of ML measured as the shortest link/connection between the front (cranial) end of the MGM and the top (dorsal) rim/edge of the spinal canal (M). For calculation of meatiness using this method the following equation was used:

$$
Y=49.6358-0.5667 S+0.2069 M
$$

Meat value $\mathrm{pH}$ Musculus longissimus (ML) and M. semimembranosus (SM) was determined 45 minutes $\left(\mathrm{pH}_{1}\right)$ and 24 hours post mortem $\left(\mathrm{pH}_{2}\right)$ by $\mathrm{pH}$-meter (Hanna, HI 83141). The print/mark of the long back muscle ML and fat was taken on tracing paper to determine the eye muscle area (AML) and fat areas which associated muscle (FA). The color of ML was determined 24 hours post-mortem measured at the same position as RF and RM (between $3^{\text {rd }}$ and $4^{\text {th }}$ rib, from caudo-cranial point of view) using Chromameter CR-400 (Minolta Co. Ltd, Tokyo, Japan). The measurements were done according to CIE L*a*b* system: lightness $\left(\mathrm{L}^{*}\right)$, redness $\left(\mathrm{a}^{*}\right)$ and yellowness $\left(\mathrm{b}^{*}\right)(\mathrm{CIE}, 1976)$.

Statistical analysis: Processing of data was done by implementation of adequate programme, i.e. use of the method of least squares (LSMLMW and MIXMDL - Harvey, $1990)$ in order to determine the significance $(\mathrm{P}<0.001)$ of systematic influences on quality traits of carcass sides. The LSD test was used to evaluate differences in each of the main values.

Model for analysis of yield and share of meat in carcass sides:

$$
y_{i j k}=\mu+G_{i}+S_{j}+b_{1}\left(X_{1}-\overline{X_{1}}\right)+\varepsilon_{i j k}
$$

where: $\mathrm{y}_{\mathrm{ijk}}-$ expression of trait in $\mathrm{k}$ individual animal, $\mathrm{i}$ genotype, $\mathrm{j}$ sex; $\mu$ - general population average, $\mathrm{G}$ genotype, $\mathrm{S}-\mathrm{sex}, \mathrm{b}_{1}$ - linear regression effect of the warm carcass side mass, $\mathrm{e}$ - random error.

\section{RESULTS AND DISCUSSION}

General population average pre-slaughter mass of investigated genotypes was $131.79 \mathrm{~kg}$ (Table 1). Mangalitsa (Genotype 1) had lower daily gain (268 g) than other genotypes and established differences were statistically very highly significant $(\mathrm{p}<0.001)$. Back fat thickness measured on different positions in Mangalitsa pigs was greater by approx. $9.3 \mathrm{~mm}$ (WBF) to $9.8 \mathrm{~mm}$ (FTMB) compared to Genotype 4. Differences between the sex are not determined $(\mathrm{p}>0.05)$. All measures traits in Table 1 depended on mass of warm carcass sides (WCM) except WBF.

The greatest difference for fat thickness RF $(+25.3$ $\mathrm{mm}$ ) was determined between Genotype 1 and Genotype 4 (Table 2.). Highest depth of muscle ML had Genotype 4 and male castrated animals $(56.37 \mathrm{~mm}$ and $47.98 \mathrm{~mm})$. Established differences between genotypes (Table 2) were 
Table 1: Effect of Genotype and sex of pre-slaughter mass, daily gain and fat thickness (WCM=110.45 kg)

\begin{tabular}{lcccc}
\hline Sources of variation & $\mathrm{PSM}^{3)}, \mathrm{kg}$ & $\mathrm{DG}, \mathrm{g}$ & WBF, $\mathrm{mm}$ & FTMB,mm \\
\hline$\mu \pm$ S.E. & $131.79 \pm 0.78$ & $369.15 \pm 8.36$ & $66.41 \pm 1.52$ & $47.00 \pm 1.60$ \\
Genotype 1 $1^{1)}$ & $133.00 \pm 1.60$ & $267.86 \pm 17.19^{\mathrm{a}}$ & $68.30 \pm 3.12^{\mathrm{a}}$ & $50.5 \pm$ \\
Genotype 2 & $134.81 \pm 1.56$ & $368.86 \pm 16.77^{\mathrm{b}}$ & $66.97 \pm 3.04^{\mathrm{a}}$ & $44.44 \pm 3.29^{\mathrm{a}}$ \\
Genotype 3 & $128.77 \pm 1.56$ & $336.91 \pm 16.82^{\mathrm{a}}$ & $67.34 \pm 3.05^{\mathrm{a}}$ & $48.29 \pm 3.21^{\mathrm{ab}}$ \\
Genotype 4 & $130.58 \pm 1.62$ & $502.95 \pm 17.43^{\mathrm{b}}$ & $59.02 \pm 3.16^{\mathrm{b}}$ & $40.74 \pm 3.33^{\mathrm{b}}$ \\
$\mathrm{P}^{2)}$ & $\mathrm{NS}$ & $* * *$ & $* *$ & $*$ \\
Female & $130.69 \pm 1.21$ & $365.61 \pm 13.07$ & $65.97 \pm 2.37$ & $45.96 \pm 2.50$ \\
Male & $132.89 \pm 1.09$ & $372.68 \pm 11.71$ & $66.85 \pm 2.12$ & $48.03 \pm 2.24$ \\
P & $\mathrm{NS}$ & $\mathrm{NS}$ & $\mathrm{NS}$ & $\mathrm{NS}$ \\
WCM(b) & $1.18^{* * *}$ & $4.01^{* * *}$ & $0.32^{\mathrm{NS}}$ & $0.66^{* * *}$ \\
\hline
\end{tabular}

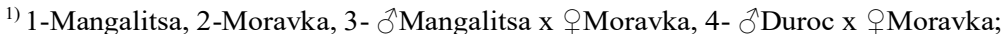

2) $\mathrm{P}$-Level of significance for factors NS - $\mathrm{P}>0.05 ; *-\mathrm{P}<0.05 ; * *-\mathrm{P}<0.01 ; * * *-\mathrm{P}<0.001$;

3) PSM-Preslaughter mass, DG-Daily gain, WBF-withers back fat thickness, FTMB-Fat thickness in the middle of the back; WCM (b)- linear effect of warm carcass side mass

Table 2: Effect of Genotype and sex of carcass quality traits (WCM=110.45 kg)

\begin{tabular}{lccccc}
\hline Sources of variation & $\mathrm{LF}^{3)}, \mathrm{mm}$ & $\mathrm{RF}, \mathrm{mm}$ & $\mathrm{RM}, \mathrm{mm}$ & $\mathrm{S}, \mathrm{mm}$ & $\mathrm{M}, \mathrm{mm}$ \\
\hline$\mu \pm$ S.E. & $52.00 \pm 1.36$ & $50.14 \pm 1.31$ & $47.06 \pm 1.00$ & $47.74 \pm 1.22$ & $61.72 \pm 1.35$ \\
Genotype 1 $^{1)}$ & $59.27 \pm 2.80^{\mathrm{a}}$ & $62.53 \pm 2.70^{\mathrm{a}}$ & $38.74 \pm 2.06^{\mathrm{a}}$ & $57.91 \pm 2.50^{\mathrm{a}}$ & $61.22 \pm 2.78^{\mathrm{ab}}$ \\
Genotype 2 & $51.98 \pm 2.73^{\mathrm{a}}$ & $45.74 \pm 2.64^{\mathrm{bc}}$ & $45.34 \pm 2.01^{\mathrm{b}}$ & $48.15 \pm 2.44^{\mathrm{ab}}$ & $61.49 \pm 2.71^{\mathrm{ab}}$ \\
Genotype 3 & $56.28 \pm 2.73^{\mathrm{a}}$ & $55.11 \pm 2.64^{\mathrm{ab}}$ & $47.77 \pm 2.01^{\mathrm{b}}$ & $48.04 \pm 2.45^{\mathrm{b}}$ & $55.51 \pm 2.72^{\mathrm{a}}$ \\
Genotype 4 & $40.48 \pm 2.83^{\mathrm{b}}$ & $37.19 \pm 2.74^{\mathrm{c}}$ & $56.37 \pm 2.09^{\mathrm{c}}$ & $36.87 \pm 2.53^{\mathrm{c}}$ & $68.66 \pm 2.82^{\mathrm{b}}$ \\
$\mathrm{P}^{2)}$ & $* *$ & $* * *$ & $* * *$ & $* * *$ & $*$ \\
Female & $49.05 \pm 2.12$ & $46.58 \pm 2.05$ & $46.14 \pm 1.57$ & $44.68 \pm 1.90$ & $62.42 \pm 2.11$ \\
Male & $54.96 \pm 1.90$ & $53.71 \pm 1.84$ & $47.98 \pm 1.40$ & $50.81 \pm 1.70$ & $61.02 \pm 1.90$ \\
P & $\mathrm{NS}$ & $*$ & $\mathrm{NS}$ & $*$ & $\mathrm{NS}$ \\
WCM(b) & $0.35^{*}$ & $0.32^{*}$ & $0.12^{\mathrm{NS}}$ & $0.19^{\mathrm{NS}}$ & $0.28^{\mathrm{NS}}$ \\
\hline
\end{tabular}

1) 1-Mangalitsa, 2-Moravka, 3- $\delta^{\lambda}$ Mangalitsa $\mathrm{x}$ QMoravka, 4- ${ }^{\Uparrow}$ Duroc $\mathrm{x}$ 9 Moravka;

2) $\mathrm{P}$-Level of significance for factors NS - $\mathrm{P}>0.05 ; *-\mathrm{P}<0.05 ; * *-\mathrm{P}<0.01 ; * * *-\mathrm{P}<0.001$;

${ }^{3)} \mathrm{LF}=$ fat tissue thickness, RF-fat tissue thickness, $\mathrm{RM}=$ diameter of ML, S- fat tissue, M- depth of ML; WCM (b)- linear effect of warm carcass side mass

statistically significant $(\mathrm{p}<0.05 ; \mathrm{p}<0.01$ and $\mathrm{p}<0.001)$. Female animals had lower fat tickness (WBF, FTMB, LF, $\mathrm{RF}$ and $\mathrm{S}$ ) and lower diameter of ML (RM), whereas the value of ML depth $(\mathrm{S})$ was higher $(+1.4 \mathrm{~mm})$ compared to male castrated animals.

In the fattening, from 31.92 to $94.33 \mathrm{~kg}$, Petrovic et al. (2007a) have found the average daily gain for Moravka of $385 \mathrm{~g} /$ day while in our studies for the same genotype the value of life daily gain of $369 \mathrm{~g}$ was determined. Petrovic et al. (2010) reported lower average body weight of animals at slaughtering (101.22 kg) compared to our study (133 kg and $134.8 \mathrm{~kg})$. Petrovic et al. (2010) had identified thinner fat tissue WBF (61.85 and $63.15: 68.30$ and $66.97 \mathrm{~mm}$ ), FTMB (43.78 and $43.22: 50.52$ and $44.44 \mathrm{~mm}$ ) and the fat thickness of the genotype $1(51.94: 57.91 \mathrm{~mm})$, while in case of genotype 2 higher values for fat thickness $\mathrm{S}$ were found (51.46: $48.15 \mathrm{~mm})$, respectively for reported and our study.

The greatest difference in share of meat to the tune of $8.3 \%$ was determined between EC 06 and FOM method (Table 3). The differences in the meatiness estimated by dissection of four parts (EC 94 and EC 06) between Genotypes 1 and 3 were almost non-existent while these differences were more pronounced when assessing meatiness based on backfat thickness and depth of the ML (FOM and TP). The thinnest fat and maximum value for gain and depth of ML had as expected the Genotype 4. Established differences from shares of muscle tissue between genotypes (Table 3 ) were very highly significant $(p<0.001)$. Females were having higher estimated lean meat as compared to the castrated male animals. The influence of gender on the estimated lean meat content was determined using FOM and the TP method $(\mathrm{p}<0.05)$ but not for the meatiness estimated by dissection (EC 94 and EC 06).

In the same study (Petrovic et al., 2010), share of muscle tissue in the carcass sides of the Moravka breed was $4.3 \%$ higher than in the carcass sides of the race Mangalitsa, whereas in our study slightly lower difference between these genotypes was identified (EC 94, 2.69\% and the EC 06, $2.03 \%$ ). Share of meat in carcass sides (EC 06) of SwallowBelly Mangalitsa was higher as compared to values determined by Kralik and Petricevic (2001) 28.8\%, Petrovic et al. (2009, 2010) $27.81 \%$ and Petrovic et al.(2011) 31.97\% and lower compared to the results by Egerszegi et al. (2003) and Petrovic et al. (2012). 
Table 3: Effect of Genotype and sex of share of meat (WCM=110.45 kg)

\begin{tabular}{lcccc}
\hline Sources of variation & EC 94), $\%$ & EC 06, \% & FOM, \% & TP, \% \\
\hline$\mu \pm$ S.E. & $34.15 \pm 0.62$ & $35.98 \pm 0.60$ & $27.68 \pm 0.89$ & $35.35 \pm 0.74$ \\
Genotype 1 $1^{1)}$ & $30.33 \pm 1.27^{\mathrm{a}}$ & $33.20 \pm 1.24^{\mathrm{a}}$ & $18.95 \pm 1.83^{\mathrm{a}}$ & $29.50 \pm 1.52^{\mathrm{a}}$ \\
Genotype 2 & $33.02 \pm 1.24^{\mathrm{a}}$ & $35.23 \pm 1.21^{\mathrm{a}}$ & $29.44 \pm 1.79^{\mathrm{b}}$ & $35.07 \pm 1.49^{\mathrm{a}}$ \\
Genotype 3 & $30.54 \pm 1.24^{\mathrm{a}}$ & $33.92 \pm 1.21^{\mathrm{a}}$ & $24.47 \pm 1.79^{\mathrm{ab}}$ & $33.91 \pm 1.49^{\mathrm{a}}$ \\
Genotype 4 & $42.72 \pm 1.28^{\mathrm{b}}$ & $43.55 \pm 1.26^{\mathrm{b}}$ & $37.85 \pm 1.86^{\mathrm{b}}$ & $42.93 \pm 1.54^{\mathrm{b}}$ \\
P $^{2)}$ & $* * *$ & $* * *$ & $* * *$ & $* * *$ \\
Female & $35.31 \pm 0.96$ & $37.20 \pm 0.94$ & $29.87 \pm 1.39$ & $37.25 \pm 1.16$ \\
Male & $32.99 \pm 0.86$ & $34.75 \pm 0.84$ & $25.49 \pm 1.25$ & $33.46 \pm 1.04$ \\
P & $\mathrm{NS}$ & $\mathrm{NS}$ & $*$ & $*$ \\
WCM(b) & $-0.07^{\mathrm{NS}}$ & $-0.10^{\mathrm{NS}}$ & $-0.21^{*}$ & $-0.05^{\mathrm{NS}}$ \\
\hline
\end{tabular}

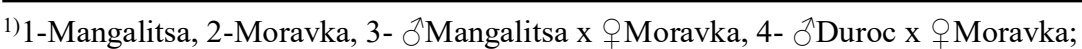

${ }^{2)} \mathrm{P}$-Level of significance for factors NS - $\mathrm{P}>0.05$; * $-\mathrm{P}<0.05$; ** - $\mathrm{P}<0.01$; *** $-\mathrm{P}<0.001$;

${ }^{3}$ EC 94 -share of meat in carcass sides (EC No 3127/94), EC 06 -share of meat in carcass sides (EC No 1197/06), FOM- share of meat determined by Fat-O-Meater, TP- share of meat determined Two-point method, WCM (b)- linear effect of warm carcass side mass.

Values of $\mathrm{pH}_{1}$ (45 minute post-mortem) of the Musculus longissimus (ML) and Musculus semimembranosus (SM) were 6.23 and 6.46 (Table 4). For both muscles was found that Genotype 3 and female animals had the highest values of $\mathrm{pH}_{1}$ and $\mathrm{pH}_{2}$. Both factors influenced statistically $(\mathrm{p}<0.05, \mathrm{p}<0.01$ and $\mathrm{p}<0.001)$ the value of $\mathrm{pH}_{2}$.

In the research of Fortina et al. (2005), in genotypes Casertana and Mora Romagnola, higher values of $\mathrm{pH}_{2}$ for
ML and SM were found compared to our genotypes, while for $\mathrm{pH}_{1}$ in both muscles similar values were observed.

The highest value for the ML surface (AML) was found in Genotype $4\left(47.52 \mathrm{~cm}^{2}\right)$, whereas for the same trait in genotype 1, the lowest value was determined $\left(24.16 \mathrm{~cm}^{2}\right)$. Established differences between genotypes (Table 5) were very highly significant $(\mathrm{p}<0.001)$. The values obtained by measuring the fat areas which associated muscle (FA)

Table 4: Effect of Genotype and sex of meat value $\mathrm{pH}$ ML and $\mathrm{pH}$ MSM (WCM=110.45 kg)

\begin{tabular}{lcccc}
\hline Sources of variation & $\mathrm{pH}_{1}-\mathrm{ML}^{3)}$ & $\mathrm{pH}-\mathrm{SM}$ & $\mathrm{pH}_{2}-\mathrm{ML}^{2}$ & $\mathrm{pH}-\mathrm{SM}^{-}$ \\
\hline$\mu \pm$ S.E. & $6.23 \pm 0.06$ & $6.46 \pm 0.06$ & $5.58 \pm 0.03$ & $5.79 \pm 0.03$ \\
Genotype 1 & $6.11 \pm 0.13^{\mathrm{a}}$ & $6.23 \pm 0.12^{\mathrm{a}}$ & $5.50 \pm 0.06^{\mathrm{ab}}$ & $5.78 \pm 0.06$ \\
Genotype 2 & $6.53 \pm 0.13^{\mathrm{b}}$ & $6.59 \pm 0.12^{\mathrm{bc}}$ & $5.65 \pm 0.05^{\mathrm{ab}}$ & $5.71 \pm 0.06$ \\
Genotype 3 & $6.59 \pm 0.13^{\mathrm{b}}$ & $6.73 \pm 0.12^{\mathrm{c}}$ & $5.71 \pm 0.05^{\mathrm{a}}$ & $5.91 \pm 0.06$ \\
Genotype 4 & $5.69 \pm 0.13^{\mathrm{c}}$ & $6.27 \pm 0.12^{\mathrm{ab}}$ & $5.46 \pm 0.06^{\mathrm{b}}$ & $5.68 \pm 0.06$ \\
$\mathrm{P}^{2)}$ & $* * *$ & $*$ & $*$ & $\mathrm{NS}$ \\
Female & $6.34 \pm 0.10$ & $6.46 \pm 0.09$ & $5.72 \pm 0.04$ & $5.97 \pm 0.04$ \\
Male & $6.13 \pm 0.09$ & $6.45 \pm 0.08$ & $5.44 \pm 0.04$ & $5.61 \pm 0.04$ \\
$\mathrm{P}$ & $\mathrm{NS}$ & $\mathrm{NS}$ & $0.00^{\mathrm{NS}}$ & $* *$ \\
WCM(b) & $0.00^{\mathrm{NS}}$ & $0.00^{\mathrm{NS}}$ & & $0.02^{* * *}$ \\
\hline
\end{tabular}

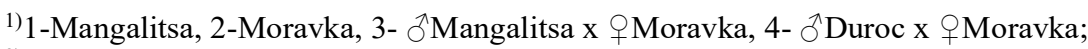

${ }^{2)} \mathrm{P}$-Level of significance for factors NS - $\mathrm{P}>0.05$; * $-\mathrm{P}<0.05$; ** $-\mathrm{P}<0.01$; *** $-\mathrm{P}<0.001$;

${ }^{3)} \mathrm{pH}_{1}$ and 2 Musculus longissimus (ML), $\mathrm{pH}_{1}$ and 2 M. semimembranosus (MSM) WCM (b)- linear effect of warm carcass side mass.

Table 5: Effect of Genotype and sex of ML and fat area and color ML (WCM=110.45 kg)

\begin{tabular}{lccccc}
\hline Sources of variation & $\mathrm{AML}^{3)}, \mathrm{cm}^{2}$ & $\mathrm{FA}, \mathrm{cm}^{2}$ & $\mathrm{~L}$ value & $\mathrm{a}^{*}$ value & $\mathrm{b}^{*}$ value \\
\hline$\mu \pm$ S.E. & $32.33 \pm 1.17$ & $49.36 \pm 1.62$ & $48.84 \pm 0.72$ & $12.79 \pm 0.50$ & $5.73 \pm 0.22$ \\
Genotype 1) & $24.16 \pm 2.41^{\mathrm{a}}$ & $55.88 \pm 3.33^{\mathrm{a}}$ & $40.13 \pm 1.48^{\mathrm{a}}$ & $11.77 \pm 1.04^{\mathrm{a}}$ & $3.73 \pm 0.45^{\mathrm{a}}$ \\
Genotype 2 & $28.51 \pm 2.35^{\mathrm{a}}$ & $51.54 \pm 3.25^{\mathrm{ab}}$ & $48.92 \pm 1.44^{\mathrm{b}}$ & $12.00 \pm 1.01^{\mathrm{a}}$ & $5.91 \pm 0.44^{\mathrm{b}}$ \\
Genotype 3 & $29.13 \pm 2.36^{\mathrm{a}}$ & $48.70 \pm 3.26^{\mathrm{ab}}$ & $50.43 \pm 1.45^{\mathrm{b}}$ & $12.10 \pm 1.01^{\mathrm{a}}$ & $6.02 \pm 0.44^{\mathrm{bc}}$ \\
Genotype 4 & $47.52 \pm 2.44^{\mathrm{b}}$ & $41.33 \pm 3.38 \mathrm{~b}$ & $55.87 \pm 1.50^{\mathrm{c}}$ & $15.30 \pm 1.05^{\mathrm{b}}$ & $7.26 \pm 0.46^{\mathrm{c}}$ \\
$\mathrm{P}^{2)}$ & $* * *$ & $\mathrm{NS}$ & $* * *$ & $\mathrm{NS}$ & $* * *$ \\
Female & $33.00 \pm 1.83$ & $46.42 \pm 2.53$ & $48.55 \pm 1.13$ & $12.57 \pm 0.79$ & $5.58 \pm 0.35$ \\
Male & $31.65 \pm 1.64$ & $52.30 \pm 2.27$ & $49.12 \pm 1.01$ & $13.02 \pm 0.71$ & $5.88 \pm 0.31$ \\
P & $\mathrm{NS}$ & $\mathrm{NS}$ & $\mathrm{NS}$ & $\mathrm{NS}$ & $\mathrm{NS}$ \\
WCM(b) & $0.27^{*}$ & $0.60^{* *}$ & $0.11^{\mathrm{NS}}$ & $-0.07 \mathrm{NS}$ & $0.00^{\mathrm{NS}}$ \\
\hline
\end{tabular}

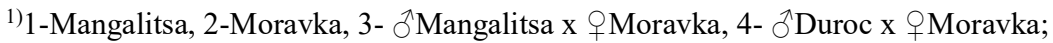

${ }^{2} \mathrm{P}$-Level of significance for factors NS - $\mathrm{P}>0.05 ; *-\mathrm{P}<0.05 ; * *$ - $\mathrm{P}<0.01 ; * * *-\mathrm{P}<0.001$;

${ }^{3)}$ AML-eye muscle area, FA-fat areas which associated muscle; WCM (b)- linear effect of warm carcass side mass. 
indicate that, although in the absolute values of the genotypes certain differences were found (Genotype 1: Genotype $4=$ $14.55 \mathrm{~cm}^{2}$ ), the difference between genotypes was not statistically significant ( $p>0.05)$. Observing these genotypes, i.e. by comparing colours of ML Mangalitsa (Genotype 1) with Genotype 4 (where we have $50 \%$ of genes of Duroc breed), it was found that Mangalitsa had a brighter ML (L* $=40.13: 55.87 \mathrm{p}<0.001)$, with a smaller proportion of red $\left(a^{*}=11.77: 15.30, \mathrm{p}>0.05\right)$ and a smaller proportion of the yellow colour $\left(b^{*}=3.73: 7.26, p<0.001\right)$. No statistically significant difference (Table 5) was determined between genders $(\mathrm{p}>0.05)$.

Compared to the research of Petrovic et al. (2007b), in our study for genotype 1 lower values were found for AML (24.16:24.43 $\left.\mathrm{cm}^{2}\right)$ and FA (55.88:81.35 $\left.\mathrm{cm}^{2}\right)$, although the animals had a higher average pre-slaughter body weight (133: $125 \mathrm{~kg})$.
The tested genotypes in our researched had darker meat (except for Genotype $1 \mathrm{~L}^{*}=40.13$ ), with a higher proportion of red and yellow in comparison with research of Fortina et al. (2005) in Genotype Casertana and Mora Romagnola.

Indigenous pig breeds Mangalitsa and Moravka is the fatty and fatty-meat breed. Considering with the low production performance (low daily gain and meatness), crossbreeding with the Duroc breed will contribute a improvement of growth and carcass traits, with the shorter fattening and higher percentage of meat content in the carcass.

\section{ACKNOWLEDGEMENTS}

This research was part of the project "Application of different breeding, selection and biotechnological methods for refinement of pigs", funded by Ministry of Education, Science and Technological Development, Republic of Serbia, Record number 31081.

\section{REFERENCES}

CIE (1976). Colorimetry: Official Recommendations of the International Commission on Illumination. Paris: Comisión Internationale de l’Èclairage. International Commission on Illumination, CIE No. 15 (1.3.1).

Comission Regulation (EC) No 1197/2006 (2006). Amending regulation (EC) No 2967/85 laying down detailed rules for the application of the Community scale for grading pig carcasses. Official Journal vol. 49 L 217, 8/8/ 2006, 0006-0007.

Comission Regulation (EC) No 1249/2008 (2008). Laying down detailed rules on the implementation of the Community scales for the classification of beef, pig and sheep carcasses and the reporting of prices thereof. Journal of European Union, L 337, 16/12/2008, 0003-0030.

Comission Regulation (EC) No $3127 / 94$ (1994). Amending regulation (EC) No 2967/85 laying down detailed rules for the application of the Community scale for grading pig carcasses. Official Journal L 330, 21/12/1994, 0043-0044.

Egerszeg, I., Rátky, J., Solti, L.and Brüssow, K.P. (2003). Mangalitsa - an indigenous swine breed from Hungary (Review). Arch. Tierzucht, 46:245-256.

Fortina, R., Barbera, S., Lussiana, C., Mimosi, A., Tassone, S., Rossi, A. and Zanardi, E. (2005). Performances and meat quality of two Italian pig breeds fed diets for commercial hybrids. Meat Sci.,71:713-718.

Harvey, W.R. (1990). PC-2 version. Ohio State University, 90 p.

Janicki, B. and Buzala, M. (2013). The role of creatine in the organism of pigsand its effect on the quality of pork: a review. Ann. Anim. Sci., 13:207-215.

Kralik, G. and Petricevic, A. (2001). Production traits of Black Slavonian pig. Proceedings: Biological diversity in animal production of Republic of Croatia, Zagreb, Croatia, pp. 115-122.

Petrovic, M., Radovic, C., Parunovic, N., Mijatovic, M., Radojkovic, D., Aleksic, S., Stanišic, N. and Popovac, M. (2010). Quality traits of carcass sides and meat of Moravka and Mangalitsa pig breeds. Biotechnol. Anim. Husb.,26:21-27.

Petrovic, M., Mijatovic, M., Radovic, C., Radojkovic, D.and Josipovic, S. (2007b). Genetic resources in pig breeding - carcass quality traits of breeds Moravka and Mangalitsa. Biotechnol. Anim. Husb., 23:421-428.

Petrovic, M., Mijatovic, M., Radojkovic, D., Radovic, C., Marinkov, G. and Stojanovic,Lj. (2007a). Genetic resources in pig breeding-Moravka. Biotechnol. Anim. Husb., 23:1-12.

Petrovic, M., Mijatovic, M., Radovic, C., Radojkovic, D.,Parunovic, N.and Stanišic, N. (2009). Genetic resources in pig breeding - carcass and meat quality traits of Moravka and Mangalitsa breeds. Proceedings of the 1st Conferenceof the Balkan Network for the Animal Reproduction Biotechnology, Sofia, pp. 14.

Petrovic, M., Radovic, C., Mijatovic, M., Radojkovic, D., Stanišic,N. and Parunovic, N. (2011). The share of tissues in pig carcass sides ofautochthonous breeds depending on the body mass and sex. Biotechnol. Anim. Husb.27:561-569. 
Petrovic, M., Radovic, C., Parunovic, N., Radojkovic, D.and Savic, R. (2012). Composition of carcass sides and quality ofmeat from Swallow-Belly Mangalitsa reared in two systems. Biotechnol. Anim. Husb.,28:303-311.

Radovic, C., Petrovic, M., Živkovic, B., Kosovac, O., Stanišic, N., Parunovic, N.and Savic, R. (2010). The effect of sire breed and sex of progeny on meatiness of pigs and methods of evaluation of carcass side quality. J. Anim. Sci.Bulgaria,XLVII:1,124-129.

Walstra, P.and Merkus, G.S.M. (1996). Report ID-DLO 96.014, Lelystad, 1-22 pp.

Živkovic, R. and Kostic, J. (1952). Prilog poznavanju crne i šarene svinje (moravke i resavke). Arhiv za poljoprivredne nauke [Contribution to the knowledge of black and colorful pigs (Moravka and Resavka). Arch. Agr. Sci.],V:10,2346. [In Serbian] 